\title{
Deferribacter autotrophicus sp. nov., an iron(III)- reducing bacterium from a deep-sea hydrothermal vent
}

\author{
G. B. Slobodkina, ${ }^{1}$ T. V. Kolganova, ${ }^{2}$ N. A. Chernyh, ${ }^{1}$ J. Querellou, ${ }^{3}$ \\ E. A. Bonch-Osmolovskaya ${ }^{1}$ and A. I. Slobodkin ${ }^{1}$
}

Correspondence

G. B. Slobodkina gslobodkina@mail.ru

\author{
${ }^{1}$ Winogradsky Institute of Microbiology, Russian Academy of Sciences, Prospect 60-letiya \\ Oktyabrya 7/2, 117312 Moscow, Russia \\ ${ }^{2}$ Bioengineering Center, Russian Academy of Sciences, Prospect 60-letiya Oktyabrya 7/1, 117312 \\ Moscow, Russia \\ ${ }^{3}$ UMR 6197, Microbiology of Extreme Environments, Ifremer, Centre de Brest, 29280 Plouzane, \\ France
}

$\mathrm{Fe}(\mathrm{III})$-reducing micro-organisms play an important role in the cycling of carbon and metals in various anaerobic ecosystems including thermal environments. Thermophilic iron reducers have been found in continental hot springs, deep terrestrial subsurface and submarine petroleum reservoirs (Slobodkin, 2005). However, the diversity of this group of prokaryotes in deep-sea hydrothermal ecosystems has been much less studied (Miroshnichenko \& Bonch-Osmolovskaya, 2006). At present, thermophilic and hyperthermophilic iron-reducing micro-organisms recovered from deep-sea habitats include three representatives of Archaea (Slobodkin et al., 2001; Kashefi et al., 2002; Reysenbach et al., 2006) and two species of Bacteria,

The GenBank/EMBL/DDBJ accession number for the 16S rRNA gene sequence of strain $\mathrm{SL}^{\top} \mathrm{O}^{\top}$ is EU407777.
Geothermobacter ehrlichii (Kashefi et al., 2003) and Deferribacter abyssii (Miroshnichenko et al., 2003).

The order Deferribacterales represents a deep lineage in the domain Bacteria (Cole et al., 2007). At the time of writing, the family Deferribacteraceae (Huber \& Stetter, 2002) comprised three genera, Deferribacter, Flexistipes and Geovibrio. Currently, the genus Deferribacter consists of three species, D. thermophilus (Greene et al., 1997), D. desulfuricans (Takai et al., 2003) and D. abyssii (Miroshnichenko et al., 2003). The type species of the genus, D. thermophilus, was isolated from a hightemperature, seawater-flooded oil reservoir located in the North Sea. The other two micro-organisms were isolated from deep-sea hydrothermal vents. $D$. desulfuricans was obtained from the Suiyo Seamount hydrothermal chimney and D. abyssii was isolated from the Rainbow hydrothermal vent field of the Mid-Atlantic Ridge. All recognized species 
of the genus Deferribacter are strictly anaerobic, thermophilic organisms capable of the oxidation of a variety of complex organic compounds and organic acids in the presence of diverse electron acceptors. In this paper, we report the isolation and characterization of a novel species of the genus Deferribacter from the deepest of the known World ocean hydrothermal fields.

Strain $\mathrm{SL} 50^{\mathrm{T}}$ was isolated from a sample of a fragment of the hydrothermal structure. The sample was collected in March 2007 during the Serpentine cruise at the Ashadze hydrothermal field $\left(12^{\circ} 58^{\prime} 21^{\prime \prime} \mathrm{N} 44^{\circ} 51^{\prime} 47^{\prime \prime} \mathrm{W}\right)$ on the Mid-Atlantic Ridge at a depth of $4100 \mathrm{~m}$. For the sample collection, sterilized microbiological boxes filled with sterile freshwater were prepared onboard. Active chimney samples were collected by the ROV Victor. On site, after opening the box lid, the freshwater was replaced by in situ seawater, the chimney fragment was introduced and the lid was closed. All following operations were done onboard under sterile conditions. Boxes with samples were stored at $4{ }^{\circ} \mathrm{C}$. An enrichment culture was initiated by inoculation of $10 \%(\mathrm{w} / \mathrm{v})$ of the sample into anaerobically prepared, bicarbonate-buffered, sterile $\left(135{ }^{\circ} \mathrm{C}, 1 \mathrm{~h}\right)$ liquid medium with lactate $\left(1.5 \mathrm{~g} \mathrm{l}^{-1}\right)$ as an electron donor and poorly crystalline $\mathrm{Fe}(\mathrm{III})$ oxide $(90 \mathrm{mM})$ as an electron acceptor. Medium composition and preparation techniques have been described previously (Slobodkin et al., 1999). Isolate SL $50^{\mathrm{T}}$ was purified from the enrichment by serial dilution in the same medium. A pure culture was obtained with sodium acetate $(18 \mathrm{mM})$ as electron donor and potassium nitrate $(10 \mathrm{mM})$ as electron acceptor by using the agarshake dilution technique with an agar block in the tube (1.5\% agar in growth medium) in medium of the following composition [per litre distilled water: $0.34 \mathrm{~g} \mathrm{KCl}$, $4.00 \mathrm{~g} \mathrm{MgCl}_{2} .6 \mathrm{H}_{2} \mathrm{O}, 0.25 \mathrm{~g} \mathrm{NH}_{4} \mathrm{Cl}, 0.14 \mathrm{~g} \mathrm{CaCl}_{2} .2 \mathrm{H}_{2} \mathrm{O}$, $0.14 \mathrm{~g} \mathrm{~K}_{2} \mathrm{HPO}_{4}, 18.00 \mathrm{~g} \mathrm{NaCl}, 5.00 \mathrm{~g} \mathrm{NaHCO}_{3}, 0.20 \mathrm{~g}$ yeast extract (Difco), $0.002 \mathrm{~g} \mathrm{Fe}\left(\mathrm{NH}_{4}\right)_{2}\left(\mathrm{SO}_{4}\right)_{2} \cdot 7 \mathrm{H}_{2} \mathrm{O}, 1 \mathrm{ml}$ traceelement solution (Slobodkin et al., 1997), $10 \mathrm{ml}$ vitamin solution (Wolin et al., 1963), $0.001 \mathrm{~g}$ resazurin, $0.50 \mathrm{~g}$ $\mathrm{Na}_{2} \mathrm{~S} .9 \mathrm{H}_{2} \mathrm{O}$, gas phase $\left.\mathrm{CO}_{2}(100 \%)\right]$. Physiological studies on substrate and electron acceptor utilization, temperature, $\mathrm{pH}$ and salinity ranges for growth, light and electron microscopy, analytical techniques, DNA extraction and determination of the $\mathrm{G}+\mathrm{C}$ content were performed as described previously (Slobodkin et al., 1999). Growth of strain $S L 50^{T}$ with poorly crystalline $\mathrm{Fe}(\mathrm{III})$ was determined by direct cell counts using light microscopy after dissolving the iron precipitate in a solution of ammonium oxalate $\left(28 \mathrm{~g} \mathrm{l}^{-1}\right)$ /oxalic acid $\left(15 \mathrm{~g} \mathrm{l}^{-1}\right) . \mathrm{pH}$ measurements and $\mathrm{pH}$-metre calibration were carried out at $60{ }^{\circ} \mathrm{C}$. $\mathrm{NO}, \mathrm{N}_{2} \mathrm{O}$ and $\mathrm{N}_{2}$ were detected by GC (Molsiv 5A column at $40{ }^{\circ} \mathrm{C}$; Ar). Ammonium and nitrite were determined by HPLC with a conductivity detector (Aquilon C1P column, $4 \mathrm{mM} \mathrm{HNO}_{3}$ for ammonium and Aquilon A1.2 column, $3.5 \mathrm{mM}$ carbonate buffer for nitrite). 16S rRNA gene amplification, sequencing and sequence analysis were done as described previously (Zavarzina et al., 2002).
In agar-shake cultures, brown lens-shaped colonies (0.2$0.5 \mathrm{~mm}$ in diameter) of strain $\mathrm{SL} 50^{\mathrm{T}}$ appeared after 710 days of incubation at $50{ }^{\circ} \mathrm{C}$. Vegetative cells of strain SL $50^{\mathrm{T}}$ were straight to bent rods, $0.5-0.6 \mu \mathrm{m}$ in width and $3.0-3.5 \mu \mathrm{m}$ in length. The cells occurred singly, in pairs or in short chains, and had one polar flagellum. Spores were not observed. Ultrathin sectioning of cells of strain SL $50^{\mathrm{T}}$ revealed that the cell wall had a typical Gram-negative structure.

The temperature range for growth of strain $\mathrm{SL} 50^{\mathrm{T}}$ was $25-$ $75{ }^{\circ} \mathrm{C}$, with an optimum at $60{ }^{\circ} \mathrm{C}$. No growth was detected at $80{ }^{\circ} \mathrm{C}$ or at temperatures up to $22{ }^{\circ} \mathrm{C}$ after incubation for 3 weeks. The $\mathrm{pH}$ range for growth was 5.0-7.5, with an optimum at $\mathrm{pH} 6.5$. No growth was observed at $\mathrm{pH} 4.5$ or 8.0. Growth of strain $\mathrm{SL}_{50}{ }^{\mathrm{T}}$ was observed at $\mathrm{NaCl}$ concentrations ranging from 1.0 to $6.0 \%(\mathrm{w} / \mathrm{v})$ with an optimum at $2.5 \%(\mathrm{w} / \mathrm{v})$, but no growth was evident in 0 or $7.0 \% \mathrm{NaCl}(\mathrm{w} / \mathrm{v})$. Yeast extract was not necessary for growth of strain $\mathrm{SL} 50^{\mathrm{T}}$ but strongly stimulated it. Potential electron acceptors were tested with sodium acetate $(18 \mathrm{mM})$ or sodium lactate $\left(1.5 \mathrm{~g} \mathrm{l}^{-1}\right)$ as an energy source in the presence of $0.20 \mathrm{~g}$ yeast extract $\mathrm{l}^{-1}$. Nitrate (potassium salt, $10 \mathrm{mM}$ ), elemental sulfur $\left(10 \mathrm{~g} \mathrm{l}^{-1}\right)$, ferric citrate $(5 \mathrm{mM})$, poorly crystalline $\mathrm{Fe}(\mathrm{III})$ oxide $(90 \mathrm{mM})$, $\mathrm{Mn}(\mathrm{IV})$ supplied as $25 \mathrm{mM}$ of $\mathrm{MnO}_{2}$ and 9,10-anthraquinone 2,6-disulfonate (AQDS; $20 \mathrm{mM}$ )) were used as an electron acceptor for growth of strain $\mathrm{SL} 50^{\mathrm{T}}$. Sulfate $(14 \mathrm{mM})$, thiosulfate and fumarate $(20 \mathrm{mM}$ each $)$ were not reduced and did not support growth. Poorly crystalline $\mathrm{Fe}(\mathrm{III})$ oxide was reduced to black magnetic precipitate with high $\mathrm{Fe}(\mathrm{II})$ content. During $\mathrm{Mn}(\mathrm{IV})$ reduction, black insoluble $\mathrm{MnO}_{2}$ turned to a light-brown precipitate that almost disappeared after prolonged incubation. No changes in colour or precipitate amount were observed in uninoculated controls with $0.20 \mathrm{~g}$ yeast extract $1^{-1}$ in growth media containing poorly crystalline $\mathrm{Fe}(\mathrm{III})$ oxide, $\mathrm{Mn}(\mathrm{IV})$ or AQDS during the incubation period at $60^{\circ} \mathrm{C}$. Elemental sulfur was reduced to hydrogen sulfide (CordRuwisch, 1985). Nitrate was reduced to ammonium; NO, $\mathrm{N}_{2} \mathrm{O}$ or nitrite were not produced in measurable amounts.

Strain $\mathrm{SL} 50^{\mathrm{T}}$ was able to grow on peptone and yeast extract $\left(10 \mathrm{~g}^{-1}\right.$ each), formate, acetate, lactate, pyruvate, fumarate, malate, propionate, succinate, maleinate and maltose $(25 \mathrm{mM}$ each) as electron donors and potassium nitrate $(10 \mathrm{mM})$ as electron acceptor in the presence of 0.20 g yeast extract $l^{-1}$. Maltose was completely oxidized to $\mathrm{CO}_{2}$ without formation of soluble fermentation products. Strain $\mathrm{SL} 50^{\mathrm{T}}$ could grow chemolithoautotrophically in the absence of yeast extract, using molecular hydrogen as an electron donor and poorly crystalline $\mathrm{Fe}(\mathrm{III})$ oxide $(90 \mathrm{mM})$ as electron acceptor and $\mathrm{CO}_{2}$ as the carbon source. When $\mathrm{Mn}(\mathrm{IV})$ was used as an electron acceptor, $\mathrm{H}_{2} / \mathrm{CO}_{2}(80 / 20, \mathrm{v} / \mathrm{v})$ was utilized and supported growth in the presence of yeast extract $\left(0.20 \mathrm{~g} \mathrm{l}^{-1}\right)$. With nitrate or sulfur as an electron acceptor molecular hydrogen did not support chemolithoautotrophic growth or growth in the presence of $0.20 \mathrm{~g}$ yeast extract $\mathrm{l}^{-1}$. Strain SL50 ${ }^{\mathrm{T}}$ was not 
able to utilize casein, tryptone, starch $\left(10 \mathrm{~g} \mathrm{l}^{-1}\right.$ each), methanol, ethanol, n-propanol, iso-propanol, n-butanol, (20 mM each), fructose, xylose, cellobiose, sucrose, Larabinose ( $25 \mathrm{mM}$ each), glycerol, butyrate or benzoate (20 $\mathrm{mM}$ each) with potassium nitrate $(10 \mathrm{mM})$ as electron acceptor.

The G $+\mathrm{C}$ content of the genomic DNA of strain SL50 ${ }^{\mathrm{T}}$ was $28.7 \mathrm{~mol} \%\left(T_{\mathrm{m}}\right)$. A comparison of 1543 nucleotides of the $16 \mathrm{~S}$ rRNA gene sequence of strain $\mathrm{SL} 50^{\mathrm{T}}$ with those available in the GenBank database showed that strain $\mathrm{SL}_{5}{ }^{\mathrm{T}}$ belonged to the genus Deferribacter (Fig. 1). Only 16S rRNA gene sequences of type strains of species with validly published names were included in the analyses. The 16S rRNA gene sequence of the novel isolate had the highest similarity with that of $D$. abyssi $\mathrm{JR}^{\mathrm{T}}(95.5 \%)$. The levels of $16 \mathrm{~S}$ rRNA gene sequence similarity with other members of the genus Deferribacter were $94.3-94.6 \%$. The trees constructed by using maximum-likelihood and maximum-parsimony algorithms displayed the same topology (data not shown). Transversion analysis (Woese et al., 1991) did not affect the phylogenetic position of the novel strain.

The novel isolate described in this report represents a micro-organism capable of reduction of $\mathrm{Fe}(\mathrm{III})$ and $\mathrm{Mn}$ (IV) as well as nitrate and sulfur, which are also common substances in deep-sea hydrothermal environments. Strain $\mathrm{SL} 50^{\mathrm{T}}$ shared many phenotypic features with recognized representatives of the genus Deferribacter (Table 1). Species of the genus Deferribacter, with the exception of $D$. thermophilus, were isolated from deep-sea hydrothermal vents. According to the electron microscopic analysis all of them have a Gram-negative type of cell-wall structure. Cells of all Deferribacter species are rod-shaped with a polar flagellum and grow under anaerobic conditions by the oxidation of a variety of complex organic compounds and organic acids in the presence of diverse electron acceptors, but not by fermentation. However, strain $\mathrm{SL} 50^{\mathrm{T}}$ differed from all representatives of the genus Deferribacter by its ability to grow chemolithoautotrophically, utilizing hydrogen as an electron donor, $\mathrm{CO}_{2}$ as a carbon source and poorly crystalline $\mathrm{Fe}(\mathrm{III})$ oxide as an electron acceptor. Strain SL $50^{\mathrm{T}}$ had the widest range of utilized electron acceptors of the recognized species of this genus. Unlike the type species of the genus, D. thermophilus, strain SL50 ${ }^{\mathrm{T}}$ was able to reduce sulfur. The ability of strain $S L 50^{\mathrm{T}}$ to reduce both $\mathrm{Fe}(\mathrm{III})$ and $\mathrm{Mn}(\mathrm{IV})$ differentiated it from $D$. abyssi, which cannot utilize $\mathrm{Mn}(\mathrm{IV})$ and $D$. desulfuricans, which is unable to use either of these metals as electron acceptors. In contrast to the type species of the genus and the phylogenetically closest species, D. abyssi, strain $\mathrm{SL}_{5}{ }^{\mathrm{T}}$ could grow on formate and propionate as substrates. Other significant characteristics that differentiate strain $S L 50^{\mathrm{T}}$ from all recognized representatives of the genus are nitrate reduction to ammonium, but not to nitrite, and the ability to use disaccharide (maltose) as an electron donor with nitrate as electron acceptor. On the basis of the phylogenetic, phenotypic and physiological properties that clearly differentiate strain $\mathrm{SL}^{\mathrm{T}}{ }^{\mathrm{T}}$ from recognized species of the genus Deferribacter, we propose that strain $\mathrm{SL} 50^{\mathrm{T}}$ represents the type strain of a novel species, with the name Deferribacter autotrophicus sp. nov.

\section{Description of Deferribacter autotrophicus sp. nov.}

Deferribacter autotrophicus (au.to.tro'phi.cus. N.L. masc. adj. autotrophicus autotrophic).

Cells are motile by means of one polar flagellum, straight to bent rods, $0.5-0.6 \mu \mathrm{m}$ in width and 3.0-3.5 $\mu \mathrm{m}$ in length; spores were not observed. Cells form brown lens-shaped colonies $(0.2-0.5 \mathrm{~mm}$ in diameter) in agar-shake cultures. Temperature range for growth is $25-75^{\circ} \mathrm{C}$, with an optimum at $60{ }^{\circ} \mathrm{C}$. $\mathrm{pH}$ range for growth is $5.0-7.5$, with an optimum at $\mathrm{pH}$ 6.5. Growth occurs at $\mathrm{NaCl}$ concentrations ranging from 1.0 to $6.0 \%(\mathrm{w} / \mathrm{v})$, with an optimum at $2.5 \%(\mathrm{w} / \mathrm{v})$. Anaerobic. Capable of chemolithoautotrophic growth using molecular hydrogen as an electron donor and ferric iron as electron acceptor and $\mathrm{CO}_{2}$ as the carbon source. Anaerobically oxidizes peptone, yeast extract (10 $\mathrm{g} \mathrm{l}^{-1}$ each), formate, acetate, lactate, pyruvate, fumarate, malate, propionate, succinate, maleinate and maltose with

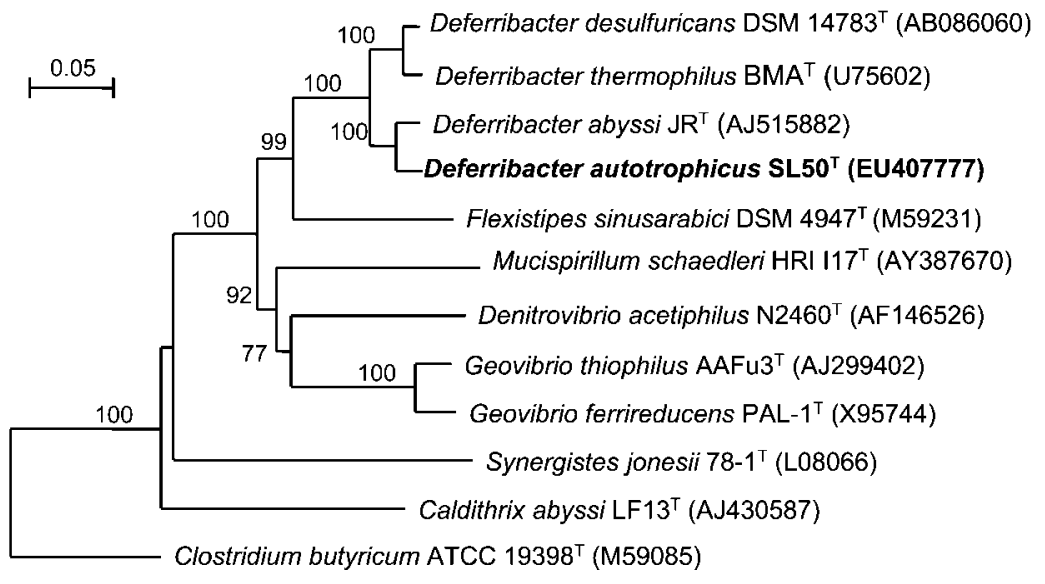

Fig. 1. Phylogenetic tree based on $16 \mathrm{~S}$ rRNA gene sequences indicating the position of strain $\mathrm{SL}^{\top} \mathrm{O}^{\top}$ within representative members of the order Deferribacterales. The 16S rRNA gene sequence of Clostridium butyricum was included as an outgroup. GenBank accession numbers are given in parentheses. Bootstrap percentages (based on 500 replications) greater than $70 \%$ are indicated at nodes. Bar, 5 substitutions per 100 nt. 
Table 1. Characteristics that differentiate strain $\mathrm{SL}_{50}^{\top}$ from other Deferribacter species

Strains: 1, strain SL50 ${ }^{\mathrm{T}}$ (D. autotrophicus sp. nov.); 2, D. abyssi $\mathrm{JR}^{\mathrm{T}}$ (data from Miroshnichenko et al., 2003); 3, D. thermophilus BMA ${ }^{\mathrm{T}}$ (Greene et al., 1997); 4, D. desulfuricans SSM1 ${ }^{\mathrm{T}}$ (Takai et al., 2003). +, Positive; -, negative.

\begin{tabular}{|c|c|c|c|c|}
\hline Characteristic & 1 & 2 & 3 & 4 \\
\hline Optimal temperature $\left({ }^{\circ} \mathrm{C}\right)$ & 60 & 60 & 60 & $60-65$ \\
\hline Elemental sulfur & + & + & - & + \\
\hline $\mathrm{Fe}(\mathrm{III})$ & + & + & + & - \\
\hline $\operatorname{Mn}(\mathrm{IV})$ & + & - & + & - \\
\hline Ethanol & - & - & - & + \\
\hline Formate & + & - & - & + \\
\hline Propionate & + & - & - & + \\
\hline Malate & + & - & - & + \\
\hline Maltose & + & - & - & - \\
\hline \multicolumn{5}{|c|}{$\begin{array}{l}\text { Chemolithoautotrophic growth with electron } \\
\text { acceptor }\end{array}$} \\
\hline DNA G $+C$ content $(\mathrm{mol} \%)$ & 28.7 & 30.8 & 34.0 & 38.6 \\
\hline
\end{tabular}

sulfur, nitrate, $\mathrm{Mn}(\mathrm{IV})$ or $\mathrm{Fe}(\mathrm{III})$ as electron acceptor in the presence of $0.20 \mathrm{~g}$ yeast extract $\mathrm{l}^{-1}$. Casein, tryptone, starch, methanol, ethanol, n-propanol, iso-propanol, n-butanol, fructose, xylose, cellobiose, sucrose, L-arabinose, glycerol, butyrate and benzoate are not utilized with nitrate as electron acceptor. Does not reduce fumarate, sulfate, thiosulfate or oxygen $(20 \%, v / v$ in the gas phase). The $\mathrm{G}+\mathrm{C}$ content of the DNA of the type strain is $28.7 \mathrm{~mol} \%\left(T_{\mathrm{m}}\right)$.

The type strain, SL50 ${ }^{\mathrm{T}}\left(=\mathrm{DSM} 21529^{\mathrm{T}}=\right.$ VKPM B-10097 ${ }^{\mathrm{T}}$ ), was isolated from a hydrothermal vent field of the MidAtlantic Ridge.

\section{Acknowledgements}

This work was supported by grant 06-04-48684-a from the Russian Foundation for Basic Research and by Federal programs 'Molecular and cell biology' and 'The origin and evolution of the biosphere' of the Russian Academy of Sciences. We acknowledge the officers and the crew of the $R / V$ Pourquoi Pas? and the ROV Victor operation team. We are also grateful to Dr Yves Fouquet, Chief Scientist of the Serpentine cruise, for his very effective contribution to the success of Ashadze hydrothermal field exploration.

\section{References}

Cole, J. R., Chai, B., Farris, R. J., Wang, Q., Kulam-Syed-Mohideen, A. S., McGarrell, D. M., Bandela, A. M., Cardenas, E., Garrity, G. M. \& Tiedje, J. M. (2007). The ribosomal database project (RDP-II): introducing $m y R D P$ space and quality controlled public data. Nucleic Acids Res 35 (Database issue), D169-D172.

Cord-Ruwisch, R. (1985). A quick method for the determination of dissolved and precipitated sulfides in cultures of sulfide-reducing bacteria. J Microbiol Methods 4, 33-36.
Greene, A. C., Patel, B. K. C. \& Sheehy, A. J. (1997). Deferribacter thermophilus gen. nov., sp. nov., a novel thermophilic manganeseand iron-reducing bacterium isolated from a petroleum reservoir. Int J Syst Bacteriol 47, 505-509.

Huber, H. \& Stetter, K. O. (2002). Family I. Deferribacteraceae fam. nov. In Bergey's Manual of Systematic Bacteriology, 2nd edn, vol. 1, pp. 465-466. Edited by D. R. Boone \& R. W. Castenholz. New York: Springer.

Kashefi, K., Tor, J. M., Holmes, D. E., Gaw Van Praagh, C. V., Reysenbach, A. L. \& Lovley, D. R. (2002). Geoglobus ahangari gen. nov., sp. nov., a novel hyperthermophilic archaeon capable of oxidizing organic acids and growing autotrophically on hydrogen with $\mathrm{Fe}(\mathrm{III})$ serving as the sole electron accepter. Int J Syst Evol Microbiol 52, 719-728.

Kashefi, K., Holmes, D. E., Baross, J. A. \& Lovley, D. R. (2003). Thermophily in the Geobacteraceae: Geothermobacter erlichii gen. nov., sp. nov., a novel thermophilic member of the Geobacteraceae from the "Bag City" hydrothermal vent. Appl Environ Microbiol 69, 2985-2993.

Miroshnichenko, M. L. \& Bonch-Osmolovskaya, E. A. (2006). Recent developments in the thermophilic microbiology of deep-sea hydrothermal vents. Extremophiles 10, 85-96.

Miroshnichenko, M. L., Slobodkin, A. I., Kostrikina, N. A., L'Haridon, S., Nercessian, O., Spring, S., Stackebrandt, E., Bonch-Osmolovskaya, E. A. \& Jeanthon, C. (2003). Deferribacter abyssi sp. nov., an anaerobic thermophile from deep-sea hydrothermal vents of the Mid-Atlantic Ridge. Int J Syst Evol Microbiol 53, 1637-1641.

Reysenbach, A. L., Liu, Y., Banta, A. B., Beveridge, T. J., Kirshtein, J. D., Schouten, S., Tivey, M. K., Von Damm, K. \& Voytek, M. A. (2006). A ubiquitous thermoacidophilic archaeon from deep-sea hydrothermal vents. Nature 442, 444-447.

Slobodkin, A. I. (2005). Thermophilic microbial metal reduction. Microbiology (English translation of Mikrobiologiia) 74, 501-514.

Slobodkin, A., Reysenbach, A.-L., Strutz, N., Dreier, M. \& Wiegel, J. (1997). Thermoterrabacterium ferrireducens gen. nov., sp. nov., a 
thermophilic anaerobic dissimilatory $\mathrm{Fe}(\mathrm{III})$-reducing bacterium from a continental hot spring. Int J Syst Bacteriol 47, 541-547.

Slobodkin, A. I., Tourova, T. P., Kuznetsov, B. B., Kostrikina, N. A., Chernyh, N. A. \& Bonch-Osmolovskaya, E. A. (1999). Thermoanaerobacter siderophilus sp. nov., a novel dissimilatory $\mathrm{Fe}(\mathrm{III})$-reducing anaerobic thermophilic bacterium. Int $J$ Syst Bacteriol 49, 1471-1478.

Slobodkin, A., Campbell, B., Cary, S. C., Bonch-Osmolovskaya, E. A. \& Jeanthon, C. (2001). Evidence for the presence of thermophilic $\mathrm{Fe}$ (III)-reducing microorganisms in deep-sea hydrothermal vents at $13^{\circ} \mathrm{N}$ (East Pacific Rise). FEMS Microbiol Ecol 36, 235-243.

Takai, K., Kobayashi, H., Nealson, K. H. \& Horikoshi, K. (2003). Deferribacter desulfuricans sp. nov., a novel sulfur-, nitrate- and arsenate-reducing thermophile isolated from a deep-sea hydrothermal vent. Int J Syst Evol Microbiol 53, 839-846.

Woese, C. R., Achenbach, L., Rouviere, P. \& Mandelco, L. (1991). Archaeal phylogeny: reexamination of the phylogenetic position of Archaeoglobus fulgidus in light of certain composition-induced artifacts. Syst Appl Microbiol 14, 364-371.

Wolin, E. A., Wolin, M. J. \& Wolfe, R. S. (1963). Formation of methane by bacterial extracts. J Biol Chem 238, 2882-2886.

Zavarzina, D. G., Tourova, T. P., Kuznetsov, B. B., BonchOsmolovskaya, E. A. \& Slobodkin, A. I. (2002). Thermovenabulum ferriorganovorum gen. nov., sp. nov., a novel thermophilic, anaerobic endospore-forming bacterium. Int J Syst Evol Microbiol 52, 17371743. 